\author{
RAFAŁ SURA \\ ORCID: 0000-0002-6899-2806 \\ Katolicki Uniwersytet Lubelski
}

\title{
EUROPEJSKI WYMIAR FUNKCJI BANKOWEGO FUNDUSZU GWARANCYJNEGO
}

\begin{abstract}
Abstrakt: Dostosowując polskie regulacje dotyczące systemu gwarantowana depozytów do odpowiednich dyrektyw Unii Europejskiej przyjętych po ogólnoświatowym kryzysie z początków XXI wieku, Bankowy Fundusz Gwarancyjny przyjął do realizacji zadania z zakresu przymusowej restrukturyzacji i uporządkowanej likwidacji. Celem niniejszej pracy jest próba odpowiedzi na pytanie, czy rezygnacja $\mathrm{z}$ funkcji pomocowej występującej w poprzednio obowiązującym stanie prawnym była słusznym zabiegiem. Z brzmienia obecnie obowiązujących przepisów wynika, że Fundusz realizuje swoje ustawowe cele przy pomocy funkcji gwarancyjnej, restrukturyzacyjnej, informacyjno-kontrolnej oraz stabilizacyjnej.
\end{abstract}

Słowa kluczowe: system gwarantowana depozytów, ogólnoświatowy kryzys, stabilność, restrukturyzacja, sektor bankowy, uporządkowana likwidacja

\section{WSTĘP}

Ogólnoświatowy kryzys z początków XXI wieku ukazał brak instrumentów prawnych, które umożliwiałyby ochronę stabilności finansowej bez konieczności korzystania ze środków publicznych. Jednym z bardziej dotkliwych skutków kryzysu z lat 2007-2009 była konieczność asygnowania gigantycznych kwot przez poszczególne rządy na ratowanie dużych banków, których upadłość doprowadziłaby do jeszcze większych strat dla podatnika i globalnego rynku² ${ }^{2}$. To z kolei

${ }^{1}$ Upadek amerykańskiego banku Lehman Brothers w 2008 roku wstrząsnął rynkami finansowymi na całym świecie i był jednym z najważniejszych wydarzeń kryzysu finansowego $z$ lat 2007-2009. Niedługo przed ogłoszeniem bankructwa bank istniejący ponad 150 lat posiadał aktywa o wartości niemal 600 miliardów dolarów, co czyniło go jedną z największych instytucji inwestycyjnych w Stanach Zjednoczonych.

2 Jedną z koncepcji dotyczących takiego zarządzania kryzysowego w sektorze instytucji finansowych na szczeblumiędzynarodowym, była idea przymusowej restrukturyzacji (ang. resolution) instytucji finansowych. Standardy o zasięgu światowym w zakresie rozwiązań legislacyjnych umożliwiających przeprowadzanie resolution wyznaczył dokument Key Attributes of Effective 
wyzwoliło wielką determinację po stronie Unii Europejskiej (dalej: UE), by zapobiec dalszemu załamaniu się systemu finansowego, bowiem w latach 2008-2012 państwa członkowskie wyłożyły ze swoich budżetów kwotę 1,5 biliona euro na pomoc zagrożonym bankom.

Komisja Europejska w 2013 roku wskazała jednoznacznie, że państwa członkowskie powinny zachęcać nierentowne podmioty do opuszczenia rynku, jednocześnie umożliwiając uporządkowane przeprowadzenie tego procesu tak, aby zachować stabilność finansową. Gdy nie ma możliwości wiarygodnego powrotu instytucji kredytowej znajdującej się w trudnej sytuacji do długoterminowej rentowności, zawsze należy rozważyć jej uporządkowaną likwidację ${ }^{3}$. Zwieńczeniem prac UE na tym etapie było przyjęcie dyrektywy dotyczącej restrukturyzacji i uporządkowanej likwidacji banków (dalej Dyrektywa BRR) ${ }^{4}$. Kraje członkowskie UE były zobowiązane implementować ją do prawa krajowego przed końcem 2014 roku.

W Polsce obecnie obowiązujące przepisy ustawy z dnia 10 czerwca 2016 roku o Bankowym Funduszu Gwarancyjnym, systemie gwarantowania depozytów oraz przymusowej restrukturyzacji ${ }^{5}$ (dalej: BFGU) stanowią implementację dyrektywy BRR oraz dyrektywy Parlamentu Europejskiego i Rady 2014/49/UE z 16 kwietnia 2014 roku w sprawie systemów gwarancji depozytów (dalej DGSD) ${ }^{6}$.

Transponując postanowienia wskazanych dyrektyw do krajowego porządku prawnego, ustawodawca starał się nadać nieco inny wymiar działalności Bankowego Funduszu Gwarancyjnego (dalej: BFG lub Fundusz). Na mocy BFGU powierzono BFG zadania z zakresu przymusowej restrukturyzacji i uporządkowanej likwidacji. Jest to novum w działalności Funduszu w porównaniu do dotychczasowej, ponad dwudziestoletniej praktyki. Postępowanie uregulowane w BFGU polega na stosowaniu przez BFG specyficznych instrumentów prawnych: przejęcie przedsiębiorstwa, instytucja pomostowa, umorzenie lub konwersja zobowiązań, wydzielenie praw majątkowych. Zastosowanie wskazanych środków ma w sposób uporządkowany wyprowadzić poddany tej procedurze podmiot z kryzysowej sy-

Resolution Regimes for Financial Institutions opracowany przez Radę Stabilności Finansowej (Financial Stability Board) skupiającą przedstawicieli najbardziej rozwiniętych państw, w tym krajów należących do G-20.

${ }^{3}$ Komunikat Komisji Europejskiej w sprawie stosowania reguł pomocy państwa w odniesieniu do środków wsparcia na rzecz banków w kontekście kryzysu finansowego, Dz.U. UE z 2013 r., C 216/01, pkt 65 .

${ }^{4}$ Dyrektywa Parlamentu Europejskiego i Rady 2014/59/UE z 15 maja 2014 roku ustanawiająca ramy prowadzenia działań naprawczych oraz restrukturyzacji i uporządkowanej likwidacji w odniesieniu do instytucji kredytowych i firm inwestycyjnych oraz zmieniająca dyrektywę Rady 82/891/EWG i dyrektywy Parlamentu Europejskiego i Rady 2001/24/WE, 2002/47/WE, 2004/25/ WE, 2005/56/WE, 2007/36/WE, 2011/35/UE, 2012/30/UE i 2013/36/EU oraz rozporządzenia Parlamentu Europejskiego i Rady (UE) Nr 1093/2010 i (UE) EMIR, Dz.Urz. UE L Nr 173, s. 190.

5 Dz.U. z 2020 r. poz. 842.

${ }^{6}$ Dz.Urz. UE L Nr 173, s. 149. 
tuacji poprzez przymusową restrukturyzację lub zapewnić jego uporządkowaną likwidację przy zachowaniu jego funkcji krytycznych i ochronie depozytów?

$\mathrm{Z}$ brzmienia obecnie obowiązującej $\mathrm{BFGU}^{8}$ wynika, że Fundusz realizuje swoje ustawowe cele przy pomocy funkcji gwarancyjnej, restrukturyzacyjnej, informacyjno-kontrolnej oraz stabilizacyjnej. Celem niniejszej pracy jest próba odpowiedzi na pytanie, czy rezygnacja w polskim ustawodawstwie z funkcji pomocowej, występującej na gruncie poprzednio obowiązującej ustawy z 14 grudnia 1994 roku o Bankowym Funduszu Gwarancyjnym ${ }^{9}$, była słusznym zabiegiem i czy w związku z tym nowy wymiar działalności BFG wytrzymuje próbę czasu.

\section{KONTEKST ODCHODZENIA OD FUNKCJI POMOCOWEJ}

Przed wejściem w życie BFGU Fundusz ustawowo był zobowiązany do eliminowania niebezpieczeństwa niewypłacalności banków poprzez udzielanie zwrotnej pomocy finansowej podmiotom objętym systemem gwarantowania depozy tów na samodzielną sanację w przypadku powstania niebezpieczeństwa niewypłacalności bądź na nabycie akcji lub udziałów banków, a także nabywanie wierzytelności, w których powstało niebezpieczeństwo niewypłacalności. Fundusz kontrolował prawidłowość wykorzystania pomocy finansowej, a także wysokości obowiązkowych opłat rocznych wnoszonych przez podmioty objęte systemem gwarantowania na rzecz BFG. Ponadto poprzednio obowiązujące regulacje zobowiązywały Fundusz do dokonywania kontroli realizacji programu postępowania naprawczego podmiotu objętego systemem gwarantowania. Pomoc mogła być udzielana bankom w formie pożyczek, gwarancji lub poręczeń oraz nabywania niezagrożonych wierzytelności banków na warunkach korzystniejszych od ogólnie stosowanych przez nie same. Celem działalności pomocowej było zmniejszanie ryzyka w systemie bankowym. Z zasady pomoc miała odnosić skutek w postaci wykluczenia bezpośredniego zagrożenia upadłością, co uzasadniało objęcie pożyczkobiorcy szczegółową analizą ze strony BFG w zakresie prawidłowości oraz optymalnego wykorzystania udzielonej pomocy finansowej. Termin „stan zagrożenia wypłacalności" zawarty w poprzednio obowiązującej BFGU nie był jednoznacznie rozumiany i z tego tytułu Fundusz posiadał kompetencję, by przy podejmowaniu decyzji w poszczególnych sprawach kierować się ocenami indy-

${ }^{7}$ M. Fedorowicz, Bankowy Fundusz Gwarancyjny jako organ przymusowej restrukturyzacji, [w:] Praktyczne i teoretyczne problemy prawa finansowego wobec wyzwań XXI wieku, red. J. Gliniecka et al., Gdańsk 2017, s. 405-416.

8 Art. 4 BFGU brzmi następująco: „Celem działalności Funduszu jest podejmowanie działań na rzecz stabilności krajowego systemu finansowego, w szczególności przez zapewnienie funkcjonowania obowiązkowego systemu gwarantowania depozytów oraz prowadzenie przymusowej restrukturyzacji”.

${ }^{9}$ Dz.U. z 2014 r. poz. 1866. 
widualnymi, każdorazowo biorąc pod uwagę normy adekwatności kapitałowej i współczynniki wypłacalności oraz limity koncentracji zaangażowań ${ }^{10}$.

\section{AKTUALNE FUNKCJE BFG}

W aktualnym stanie prawnym, to jest od 9 października 2016 roku (data wejścia w życie obowiązującej UBFG), ustawodawca świadomie zrezygnował z wypełniania swoich ustawowych zadań poprzez udzielanie zwrotnej pomocy finansowej podmiotom zagrożonym niewypłacalnością. Odstąpienie od realizacji przez Fundusz funkcji pomocowej wynikało przede wszystkim z następujących powodów. Po pierwsze dyrektywa BRR wprowadziła do unijnego porządku prawnego uprawnienia pozwalające przeprowadzić restrukturyzację podmiotu zagrożonego upadłością bez stwarzania zagrożenia dla deponentów i stabilności finansowej, obciążając zarazem kosztami prowadzonych działań akcjonariuszy i wierzycieli podmiotu zagrożonego. Po drugie, dyrektywa BRR dopuściła działania obejmujące rządowe instrumenty stabilizacji finansowej. Po trzecie dyrektywa DGSD wzmocniła zasady wykorzystania środków gromadzonych w systemach gwarantowania depozytów, a także finansowania postępowania przymusowej restrukturyzacji. Po czwarte bieżąca obserwacja dowiodła, że obniża się efektywność narzędzi pomocowych ${ }^{11}$. Po piąte $\mathrm{z}$ uwagi na dążenie do zapewnienia zgodności regulacji w tej materii z zasadami udzielania pomocy publicznej podmiotom z unijnego sektora finansowego ${ }^{12}$. Po szóste przez wzgląd na rekomendacje instytucji międzynarodowych dążących do ograniczenia pokusy nadużyć i zwiększenia dyscypliny rynkowej ${ }^{13}$.

Jak wskazano powyżej, pod rządami nowej BFGU zrezygnowano z funkcji pomocowej. Uwzględniając aspekt historyczny gromadzenia składek i dyspono-

10 P. Zawadzka, Komentarz do art. 5, [w:] Ustawa o Bankowym Funduszu Gwarancyjnym, systemie gwarantowania depozytów oraz przymusowej restrukturyzacji. Komentarz, red. P. Zawadzka, P. Zimmerman, R. Sura, Warszawa 2017, s. 78.

11 A. Kulesza, Wplyw systemu gwarantowania depozytów na ryzyko niewyplacalności sektorów bankowych $w$ wybranych krajach europejskich w latach 2004-2016, „Bezpieczny Bank” 2020, nr 4, s. 8 n.

12 Zob. Pomoc publiczna. Doświadczenia wybranych sektorów gospodarki, red. M. Kożuch, Kraków 2017, s. 11.

13 Zdaniem A. Jurkowskiej-Zeidler zmiany nie dotyczą jedynie architektury instytucjonalnej, ale także ram prawnych dla podejmowania i prowadzenia działalności przez instytucje finansowe (świadczenia usług finansowych) na unijnym rynku finansowym, zwłaszcza w obszarze nadzoru ostrożnościowego i zarządzania sytuacjami kryzysowymi. Oznacza to, że na poziomie UE scentralizowano także więcej kompetencji i uprawnień wykonawczych w oparciu o nowe organy regulacyjne i decyzyjne oraz w pełni zharmonizowane prawodawstwo UE. Szerzej zob. A. Jurkowska-Zeidler, Spór komisji nadzoru finansowego Abris Capital Partners. Międzynarodowe umowy o ochronie inwestycji (bit) pomiędzy państwami członkowskimi V Prawo Unii Europejskiej, „Gdańskie Studia Prawnicze” 2019, nr 2, s. 355-370. 
wania środkami funduszu pomocowego w zakresie wypłat środków gwarantowanych, przeniesiono jednak całość środków zgromadzonych na tym funduszu do funduszu gwarancyjnego. Natomiast zupełnie ekstraordynaryjnym instrumentem pozostającym w ręku regulatora jest pomoc udzielana instytucjom finansowym w warunkach zagrożenia stabilności finansowej. Komisja Europejska wprost wskazuje w przywołanym wyżej komunikacie, że w sytuacji utrzymującego się napięcia na rynkach finansowych i biorąc pod uwagę ryzyko wystąpienia szerzej zakrojonego negatywnego efektu mnożnikowego, uznaje, że pozostaną spełnione wymogi dotyczące stosowania art. 107 ust. 3 lit. b Traktatu o funkcjonowaniu Unii Europejskiej ${ }^{14} \mathrm{w}$ odniesieniu do pomocy państwa w sektorze finansowym.

Wyrażony w art. 4 BFGU nakaz działań na rzecz stabilności krajowego systemu finansowego jest wartością o charakterze fundamentalnym dla całego ustawodawstwa gospodarczego w Polsce i stanowi aksjologiczną bazę dla wszelkich treści normatywnych wyrażonych w BFGU. Stabilność finansowa i ochrona deponentów są wartościami, które należy chronić w interesie publicznym. Zatem zasadne jest wprowadzanie przepisów służących ograniczeniu ryzyka zagrożeń dla stabilności finansowej. Przeciwdziałanie zagrożeniom dla bezpieczeństwa ekonomicznego państwa stanowi cel istnienia sieci bezpieczeństwa finansowego, jedną bowiem z wartości konstytuujących bezpieczeństwo ekonomiczne jest zapewnienie przez państwo bezpieczeństwa rynku finansowego w aspekcie gromadzenia oszczędności obywateli. Stabilność finansowa jest chroniona w sposób szczególny, gdyż jest conditio sine qua non wzrostu gospodarczego. Stąd też uznawana jest za dobro publiczne, a wszelkie działania mające na celu jej utrzymanie są podejmowane w interesie publicznym, wszak koszty kryzysów gospodarczych ponosi ostatecznie całe społeczeństwo ${ }^{15}$.

Funkcje Funduszu wiążą się w sposób bezpośredni z pozycją, jaką zajmuje on wśród innych podmiotów stojących na straży bezpieczeństwa finansowego państwa oraz z misją, jaka wyłania się z regulacji prawnych określających jego działalność. Analizując określone ustawowo cele i zadania Funduszu, można sprecyzować misję BFG, gdyż jako podmiot prawa publicznego realizuje on — jak każda inna organizacja - misję właśnie. W przypadku Funduszu jest to niewątpliwie misja publiczna. Przyjmując za punkt wyjścia nauki o zarządzaniu, można by z całą pewnością przyjąć w odniesieniu do administracji publicznej jako całości i poszczególnych elementów jej struktury, że jest organizacją. Natomiast procesy administrowania, działania administracji, można by ujmować jako procesy w ramach poszczególnych rodzajów organizacji będących elementami szerokiej struktury administracji publicznej. W takim ujęciu BFG należy zakwalifikować jako organizację będącą elementem struktury organizacyjnej państwa. Natomiast sama

14 Dz.U. C 202 z 7 czerwca 2016 roku.

15 Zob. A. Jurkowska-Zeidler, Bezpieczeństwo rynku finansowego w świetle prawa Unii Europejskiej, Warszawa 2008, s. 167 oraz tejże, Światowe dobro publiczne, „Gazeta Bankowa” 2005, s. $32 \mathrm{n}$. 
misja organizacji jest rozmaicie definiowana. Pojęcie to jest zazwyczaj podawane w dwóch wymiarach: jako element strategii i jako kategoria filozoficzno-etyczna. Przy takim podejściu, rozumiana jako element taktyki, misja jest narzędziem zarządzania strategicznego ${ }^{16}$. W związku z tym do sformułowania misji publicznej BFG będzie przydatna definicja zakładająca, że stanowi ona składową jego strategii. W dobie spadku zaufania do instytucji finansowych spowodowanym kryzysami o zasięgu globalnym i regionalnym misją Funduszu jest podejmowanie działań na rzecz stabilności krajowego systemu finansowego, bezpieczeństwa podmiotów objętych systemem gwarantowania depozytów oraz wzrostu zaufania do krajowego systemu finansowego. Przy czym wszystkie wymienione elementy powinny mieć jednakowy priorytet, niezależnie od każdorazowo tymczasowego rozłożenia akcentów ${ }^{17}$.

Przyjmuje się, że realizacja zadań i funkcji BFG wpływa bezpośrednio na stabilność i bezpieczeństwo systemu finansowego, a także chroni interesy wszystkich uczestników rynku ${ }^{18}$.

\subsection{FUNKCJA GWARANCYJNA.}

BFG nie mógłby wypełniać swojej misji, gdyby nie realizował swoich funkcji. Funkcja gwarancyjna wiąże się z wypłatą depozytów do maksymalnego pułapu równowartości w złotych 100 tysięcy euro ${ }^{19}$. Z historycznego punktu widzenia można powiedzieć, że potrzeba jej realizacji była przyczyną powołania tej instytucji do życia. Zasadniczo działalność gwarancyjna Funduszu nie była też nigdy przedmiotem krytyki, ani ze strony przedstawicieli doktryny, ani instytucji rynku finansowego. Zwracano natomiast jednoznacznie uwagę, że realizacja tej funkcji służy podniesieniu bezpieczeństwa i stabilności całego sektora bankowego ${ }^{20}$.

16 J. Supernat, Zarządzanie, Wrocław 2005, s. 370.

17 R. Sura, Komentarz do art. 4, [w:] Ustawa o Bankowym Funduszu Gwarancyjnym, systemie gwarantowania depozytów oraz przymusowej restrukturyzacji. Komentarz, red. P. Zawadzka, P. Zimmerman, R. Sura, Warszawa 2017, s. 69.

18 I. Kropacz, Stabilność systemu finansowego i bezpieczeństwo polskiego systemu gwarantowania depozytów, „Finanse i Prawo Finansowe” 2017, nr 4, s. 18; Ł. Wojciechowski, Bankowy Fundusz Gwarancyjny jako instytucja bezpieczeństwa finansowego w świetle wybranych aspektów funkcjonowania systemu gwarantowania depozytów, „Zeszyty Naukowe Wyższej Szkoły Ekonomii i Innowacji w Lublinie” 2016, nr 1 s. 20.

19 Środki, o których mowa w art. 17 i art. 18 BFGU, są objęte ochroną gwarancyjną w danym podmiocie przynależącym do systemu gwarantowania od dnia ich wniesienia na rachunek w tym podmiocie, nie później jednak niż w dniu poprzedzającym dzień spełnienia warunku gwarancji, a w przypadku należności wynikających z czynności bankowych lub z przeprowadzania przez kasę rozliczeń finansowych, o ile czynność ta lub rozliczenie zostały dokonane przed dniem spełnienia warunku gwarancji, do wysokości równowartości w złotych 100000 euro — w całości (zob. art. 24 ust. 1 BFGU).

20 Zob. Z. Ofiarski, Istota i zakres kontroli wykonywanej przez Bankowy Fundusz Gwarancyjny, „Białostockie Studia Prawnicze” 2019, nr 23; M. Zygierewicz, Bankowy Fundusz Gwa- 
Sposób finansowania tej działalności polega na ponoszeniu finansowego ciężaru wypłaty kwot gwarantowanych depozytów przez banki dobrze zarządzane, ponieważ wypłacone środki gwarantowane otrzymują klienci banków źle zarządzanych. Pomimo takiej konstrukcji, funkcja gwarancyjna ma korzystny wpływ na istnienie systemu gwarantowania depozytów in genere, przede wszystkim dlatego, że zmniejsza ryzyko wystąpienia „efektu domina”, czyli przenoszenia się trudności finansowych z uczestników systemu o złej kondycji na tych w dobrej sytuacji ekonomicznej.

Podkreślenia wymaga, że w ślad za dyrektywą DGSD polska BFGU wprowadza zróżnicowanie poziomu składek wnoszonych do Funduszu przez podmioty zobowiązane, w zależności od ryzyka związanego z ich działalnością, zmieniając jednocześnie podstawy ich naliczania. Istotną zmianą na korzyść deponentów jest skrócenie czasu wypłaty środków gwarantowanych z 20 do siedmiu dni oraz ustanowienie poziomów docelowych funduszy, z których finansowana jest działalność gwarancyjna, określenie zasad wypłat środków gwarantowanych w przypadku prowadzenia przez podmiot objęty obowiązkowym systemem gwarantowania działalności transgranicznej, określenie zasad wykorzystania środków zgromadzonych na funduszu gwarancyjnym do finansowania działań z zakresu przymusowej restrukturyzacji oraz określenie zasad zaciągania i udzielania pożyczek przez BFG na wypłaty środków gwarantowanych realizowane odpowiednio przez Fundusz i systemy gwarantowania depozytów w państwach członkowskich innych niż Polska ${ }^{21}$.

\subsection{FUNKCJA RESTRUKTURYZACYJNA}

Ogólnoświatowy kryzys z lat 2007-2008 wywołał na tyle trwałe skutki, że część ekonomistów długoletni stan spowolnienia w światowej gospodarce określała mianem sekularnej stagnacji ${ }^{22}$. Kryzys ten obnażył jednak przede wszystkim brak odpowiedniego instrumentarium, które pozwoliłoby podejmować skuteczne działania chroniące stabilność finansową bez konieczności korzystania ze środków publicznych. $Z$ tego względu zostało podjętych wiele inicjatyw na poziomie międzynarodowym, mających na celu stworzenie ram zarządzania kryzysowego. W Stanach Zjednoczonych, Kanadzie, Japonii, Brazylii, Meksyku i w niektórych państwach azjatyckich stworzono odrębny reżim prawny regulujący przymusową

rancyjny - potrzeby ewolucji działalności gwarancyjnej i pomocowej, „Bezpieczny Bank” 2005, nr 2, s. 49 n.

21 R. Sura, op. cit., s. 70.

22 Zob. L. Summers, U.S. Economic Prospects: Secular Stagnation, Hysteresis, and the Zero Lower Bound, „Business Economics, National Association for Business Economics” 2014, nr 2, s. 65 . 
restrukturyzację instytucji finansowych w trybie pozasądowym przez nowopowołane bądź już istniejące organy ${ }^{23}$.

W Unii Europejskiej wprowadzano Dyrektywę BRR, która z kolei wprowadziła obowiązek implementowania do krajowych porządków prawnych regulacji nadających odpowiednim organom uprawnienia do prowadzenia przymusowej restrukturyzacji. Kraje członkowskie EU miały wprowadzić tę zasadę przed 1 stycznia 2015 roku z zastrzeżeniem regulacji dotyczących umorzenia lub konwersji długu, które mogły zostać wprowadzone rok później. Treść art. 3 ust. 3 Dyrektywy BRR jednoznacznie przesądza, że organami ds. restrukturyzacji i uporządkowanej likwidacji mogą być banki centralne, właściwe ministerstwa lub inne organy administracji publicznej oraz organy, którym powierzono uprawnienia $\mathrm{w}$ zakresie administracji publicznej.

Zgodnie z postanowieniami BFGU Fundusz realizuje funkcję restrukturyzacyjną w szczególności poprzez: tworzenie planów przymusowej restrukturyzacji, ocenę ich wykonalności oraz uprawnień do wydawania zaleceń instytucjom finansowym objętym zakresem podmiotowym regulacji w zakresie usunięcia stwierdzonych przeszkód dla skutecznej realizacji postępowania przymusowej restrukturyzacji; wykonywanie uprawnień do dokonywania umorzenia lub konwersji instrumentów kapitałowych oraz wydawania decyzji w przedmiocie wszczęcia postępowania przymusowej restrukturyzacji oraz prowadzenia postępowania, w tym tworzenia podmiotu zarządzającego aktywami oraz instytucji pomostowej; uprawnienia do zawieszania w postępowaniu przymusowej restrukturyzacji działalności podmiotu objętego systemem gwarantowania depozytów; uprawnienia do nakładania na podmioty objęte systemem gwarantowania depozytów obowiązku utrzymywania odpowiedniego poziomu zobowiązań podlegających umorzeniu lub konwersji.

\subsection{FUNKCJA ANALITYCZNO-KONTROLNA}

Funkcja ta obejmuje gromadzenie i wykorzystywanie informacji o podmiotach objętych systemem gwarantowania. Ważne jest traktowanie jej w ujęciu aktywnym, gdzie gromadzenie informacji stanowi podstawę identyfikowania stanu zagrożenia, kontroli wykorzystania pomocy albo wręcz różnicowania kosztów ponoszonych przez podmioty systemu gwarantowania ze względu na generowany poziom ryzyka. Analiza realizowana musi być w sposób samodzielny i niezależny,

23 Część rozwiązań wychodzi naprzeciw rekomendacjom Rady Stabilności Finansowej (Financial Stability Board) będącej stowarzyszeniem banków centralnych i instytucji finansowych powołanym dla celów międzynarodowego ujednolicania przepisów. W rekomendacjach dotyczących postępowania przymusowej restrukturyzacji rada ta wskazuje, że cechą pożądanych ram prawnych powinna być odporność na ryzyko zaniechania przez sieć stabilności finansowej (zob. Uzasadnienie rządowego projektu ustawy o Bankowym Funduszu Gwarancyjnym, systemie gwarantowania depozytów oraz przymusowej restrukturyzacji, Druk sejmowy nr 215, s. 37). 
a obejmować powinna również trendy rozwojowe w gospodarce, sytuację na międzynarodowych rynkach finansowych, ale przede wszystkim na bieżąco oceniać istniejące i ewentualne zagrożenia dla stabilności polskiego systemu finansowego. Działalność ta odnosi się do monitorowania sytuacji poszczególnych podmiotów $\mathrm{i}-\mathrm{w}$ razie potrzeby — wdrażania procedur prewencyjnych. Służy także określaniu zapotrzebowania na środki finansowe systemu gwarantowania depozytów ${ }^{24}$.

Funkcja analityczna realizowana jest na kanwie współpracy z pozostałymi podmiotami sieci bezpieczeństwa finansowego i ustawowego wyposażenia BFG w prawo dostępu do informacji o podmiotach objętych systemem gwarantowania depozytów. Prawo to konkretyzuje się w dwojaki sposób. Mianowicie przez wzajemne porozumienia zawierane pomiędzy podmiotami tworzącymi Komitet Stabilności Finansowej, a także poprzez ścisłą współpracę w ramach Komitetu Stabilności Finansowej ${ }^{25}$. Dyrektywa BRR nakłada na organy przymusowej restrukturyzacji obowiązek opracowania planów dla podmiotów objętych zakresem obowiązującej regulacji. Tworząc plan, Fundusz dokonuje analizy skutków zastosowania poszczególnych instrumentów oraz uprawnień nadawanych ustawą i wybiera je, kierując się kryterium skuteczności w realizacji celów postępowania przymusowej restrukturyzacji w okolicznościach konkretnego przypadku, a w następnej kolejności stosuje kryterium efektywności kosztowej. Gdyby Fundusz nie był wyposażony w prawne możliwości realizacji funkcji analityczno-kontrolnej, wątpliwe okazałoby się realizowanie jego funkcji restrukturyzacyjnej. Ustawodawca słusznie postąpił, że w takim zakresie zdecydował się implementować postanowienia art. 11 ust. 1 lit. a i b oraz art. 11 ust. 2 BRR do BFGU, które jednoznacznie przesadzają o tym, że przygotowanie przez Fundusz planu przymusowej restrukturyzacji, w tym dobór instrumentów, których zastosowanie pozwoli osiągnąć cele postępowania, wymaga pełnej znajomości zakresu usług, struktury organizacyjnej i prawnej, profilu ryzyka oraz powiązań podmiotu, dla którego tworzony jest plan. W związku z powyższym kluczowe jest zapewnienie Funduszowi dostępu do wszystkich informacji potrzebnych do przeprowadzenia analizy podmiotu i jego działalności, i opracowania planu. Ostatecznie Fundusz wyposażony został w uprawnienie do nałożenia na podmiot krajowy obowiązku współpracy w zakresie opracowania i aktualizacji planu przymusowej restrukturyzacji. Fundusz posiada ustawowe uprawnienia kontroli prawidłowości danych zgromadzonych w systemach wyliczania. Celem tych kontroli jest identyfikacja błędów i poprawa jakości danych w systemach wyliczania oraz umożliwienie szybkiej realizacji potencjalnych wypłat. Kontrole realizowane przez Fundusz przeprowadzane są zgodnie z przygotowywanym planem kontroli ${ }^{26}$.

24 Zob. J. Szambelańczyk, Miejsce i rola Bankowego Funduszu Gwarancyjnego w sieci bezpieczeństwa systemu finansowego w Polsce, „Bezpieczny Bank” 2005, s. 74.

25 Zob. ustawa z dnia 7 listopada 2008 roku o Komitecie Stabilności Finansowej, Dz.U. z 2008 r. nr 209, poz. 1317 ze zm.

26 R. Sura, op. cit., s. 71. 


\subsection{FUNKCJA STABILIZACYJNA}

Treść art. 1 oraz art. 4, a także dająca się skonstruować po analizie pozostałych przepisów BFGU misja Funduszu stanowią podstawę do wyodrębnienia czwartej funkcji Funduszu, którą można określić mianem funkcji stabilizacyjnej. Funkcja ta jest jakby klamrą spinającą funkcję gwarancyjną, restrukturyzacyjną oraz analityczno-kontrolną. Wyraża się ciągłym monitorowaniem sytuacji w sektorze bankowym na podstawie danych od Ministra Finansów, Narodowego Banku Polskiego oraz Komisji Nadzoru Finansowego i inicjowaniem działań utrzymujących stabilność w sektorze, także, ale i przede wszystkim, poprzez twórczy udział w pracach Komitetu Stabilności Finansowej. W art. 5 ust. 7 BFGU ustawodawca zawarł delegację dla ministra właściwego do spraw instytucji finansowych o możliwości określenia w drodze rozporządzenia, po zasięgnięciu opinii Prezesa Narodowego Banku Polskiego i Przewodniczącego Komisji Nadzoru Finansowego, dodatkowych działań Funduszu na rzecz stabilności krajowego systemu finansowego oraz trybu i sposobu ich wykonania, kierując się koniecznością zapewnienia stabilności krajowego systemu finansowego. Można wiec stwierdzić, że funkcje gwarancyjna, restrukturyzacyjna, analityczno-kontrolna i stabilizacyjna są immanentnymi cechami BFG wynikającymi z jego prawnego charakteru. Choć zachodzi pytanie, jak w praktyce będzie realizowany zawarty w art. 3 ust. 3 Dyrektywy BRR postulat operacyjnej czy strukturalnej niezależności oraz unikania konfliktów interesu pomiędzy poszczególnymi funkcjami Funduszu w kontekście ustroju organów, z którego wynika, że rada oraz zarząd BFG są upoważnione do działań w drodze wydawania decyzji dotyczących zarówno gwarantowania depozytów, jak też przymusowej restrukturyzacji. Może to potencjalnie prowadzić do konfliktu interesów pomiędzy funkcjami BFG w obu wymienionych obszarach. Choć a contrario powoływanie w ramach Funduszu odrębnych organów, które miałyby się zajmować wyłącznie jedną z funkcji, nie byłoby celowe ${ }^{27}$.

\section{WNIOSKI}

Wiarygodność systemu ochrony depozytów jest szczególnie istotna podczas kryzysów gospodarczych. Mamy wtedy do czynienia zarówno ze wzrostem ryzyka w wielu obszarach działalności banków, jak i z podwyższoną wrażliwością społeczną klientów sektora bankowego w kontekście bezpieczeństwa ich depozytów. Dowodem na to jest między innymi fakt, że w pierwszym okresie pandemii COVID-19 w Polsce banki musiały sprostać zwiększonym wypłatom depozytów ${ }^{28}$.

27 Ibidem, s. 72.

28 S. Kujawa, Wdrożenie Dyrektywy Parlamentu Europejskiego i Rady 2014/49/UE z dnia 16.04.2014 r. w sprawie systemów gwarancji depozytów przez państwa członkowskie Unii Europejskiej, „Bezpieczny Bank” 2020, nr 4, s. 34. 
Od początku działalności, to jest od 1995 do końca 2019 roku, Fundusz wypłacił środki gwarantowane deponentom 97 banków (w tym pięciu banków komercyjnych i 92 banków spółdzielczych) oraz jedenastu kas. W tym samym okresie przeznaczono kwotę 3022 milionów zł na wypłaty środków gwarantowanych dla 360,2 tysięcy uprawnionych deponentów banków oraz kwotę 4 366,6 milionów zł na wypłaty środków gwarantowanych dla 246,5 tysięcy uprawnionych deponentów kas ${ }^{29}$.

Poziom pokrycia depozytów w Polsce, pomimo wielu wypłat z tytułu upadłości banków, nadal pozostaje na poziomie wyższym niż oczekiwany i wynosił na koniec 2019 roku 1,78\%. Bezpieczny pułap w krajowym systemie ochrony depozytów w Polsce to konsekwencja systemu hybrydowego, upadłości relatywnie nieistotnych dla systemu, wysokiego współczynnika (ponad poziom minimalny) zapisanego w BFGU oraz przede wszystkim wysokich obciążeń finansowych banków w tym zakresie ${ }^{30}$.

Doświadczenia ogólnoświatowego kryzysu z początków XXI wieku dowiodły, że podstawy prawne i procedury operacyjne w zakresie restrukturyzacji i uporządkowanej likwidacji banków powinny być standardem, zwłaszcza na jednolitym rynku europejskim. Europa wykazała poważne zaległości w tym obszarze, co w efekcie okazało się niezmiernie kosztowne dla podatników. Dlatego konieczne stało się uzupełnienie krajowych sieci bezpieczeństwa finansowego poprzez wyznaczenie instytucji odpowiedzialnej za przeprowadzenie procesu resolution. Istotne jest przy tym zapewnienie tejże insty tucji szerokich uprawnień w zakresie ingerencji w prawa właścicieli i wierzycieli oraz wyposażenie w odpowiednie narzędzia, dzięki którym będzie ona mogła szybko i sprawnie reagować w sytuacji zagrożenia upadłością banku. Ze względu na komplementarność działań organów nadzoru i resolution ważne jest także zapewnienie mechanizmów wymiany informacji oraz współpracy pomiędzy tymi instytucjami na etapie prewencji oraz $\mathrm{w}$ ramach zarządzania kryzysem $\mathrm{w}$ banku ${ }^{31}$.

Kilka lat obowiązywania BFGU, która implementowała dyrektywę BRR oraz dyrektywę DGSD, wydatnie ukazuje, że realizując swoją misję i szczegółowo skatalogowane zadania przy pomocy funkcji gwarancyjnej, restrukturyzacyjnej, informacyjno-kontrolnej oraz stabilizacyjnej, Fundusz czyni to w sposób bezpieczny dla stabilności sektora bankowego. Zaś samo odstąpienie od funkcji pomocowej obecnej w poprzednio obowiązującym stanie prawnym było zabiegiem słusznym, swoistym signum temporis ${ }^{32}$ nadającym nowy, europejski wymiar funkcjom BFG.

29 Raport roczny Bankowego Funduszu Gwarancyjnego za 2019 rok, Warszawa 20019, s. 23 n.

30 S. Kujawa, op. cit., s. 47.

31 O. Szczepańska, A. Dobrzańska, B. Zdanowicz, Resolution, czyli nowe podejście do banków zagrożonych upadłościa, Warszawa 2015, s. 70

32 „W dniu 14 września 2007 roku przed oddziałami brytyjskiego banku Northern Rock w Londynie ustawiły się kolejki deponentów wycofujących swoje wkłady. Był to pierwszy run na bank w Wielkiej Brytanii od 1866 roku. Po kilku miesiącach bezskutecznego poszukiwania 
Bieżąca obserwacja dowodziła bowiem, że znacząco obniża się efektywność narzędzi pomocowych, a możliwość ich stosowania, zamiast ograniczać zjawisko moral hazard, wzmagała pokusę nadużyć i obnażała brak dyscypliny rynkowej. $\mathrm{Z}$ kolei trwające postępowania, prowadzone obecnie przez BFG w stosunku do banków i kas bez zaangażowania środków budżetu państwa, dowodzą tego, że wprowadzone w BFGU rozwiązania szczegółowe wytrzymują próbę czasu.

\title{
THE EUROPEAN DIMENSION OF THE BANK GUARANTEE FUND FUNCTION
}

\author{
Summary
}

By adjusting Polish regulations on the deposit guarantee system to the relevant directives of the European Union adopted after the global crisis at the beginning of the $21^{\text {st }}$ century, the Bank Guarantee Fund adopted tasks in the field of resolution. The aim of this study is to try to answer the question whether the resignation from the support function that was present in the previous legal status was the right thing to do. The wording of the regulations currently in force shows that the fund achieves its statutory objectives by means of the guarantee function; the restructuring function; information and control function and stabilization function.

Keywords: deposit guarantee system, global crisis, stability, restructuring, banking sector, resolution

\section{BIBLIOGRAFIA}

\author{
ŹRÓDŁA PRAWA
}

Traktat o funkcjonowaniu Unii Europejskiej, Dz.U. C 202 z 7 czerwca 2016 roku.

Dyrektywa Parlamentu Europejskiego i Rady 2014/59/UE z 15 maja 2014 roku ustanawiająca ramy na potrzeby prowadzenia działań naprawczych oraz restrukturyzacji i uporządkowanej likwidacji w odniesieniu do instytucji kredytowych i firm inwestycyjnych oraz zmieniająca dyrektywę Rady 82/891/EWG i dyrektywy Parlamentu Europejskiego i Rady 2001/24/WE, 2002/47/WE, 2004/25/WE, 2005/56/WE, 2007/36/WE, 2011/35/UE, 2012/30/UE i 2013/36/ EU oraz rozporządzenia Parlamentu Europejskiego i Rady (UE) Nr 1093/2010 i (UE) EMIR, Dz.Urz. UE L Nr 173.

prywatnego inwestora rząd Wielkiej Brytanii zdecydował się na nacjonalizację banku. Decyzja ta mogła zostać podjęta dopiero po wprowadzeniu specjalnych zmian w prawie dopuszczających możliwość pozbawienia akcjonariuszy praw do akcji banku na rzecz Skarbu Państwa za odpowiednim odszkodowaniem, którego wartość zależała od niezależnej wyceny. Władze brytyjskie wyjaśniały, że decyzja była podyktowana koniecznością ochrony stabilności całego systemu finansowego, a nie chęcią ratowania banku Northern Rock. Był to również swoisty akt bezradności rządu, ponieważ nie dysponował on wówczas ani prawnymi, ani operacyjnymi środkami radzenia sobie z sytuacją kryzysową w bankach bez konieczności sięgania po publiczne pieniądze” (O. Szczepańska, A. Dobrzańska, B. Zdanowicz, op. cit., s. 8 n.). 
Dyrektywa Parlamentu Europejskiego i Rady 2014/49/UE z 16 kwietnia 2014 roku w sprawie systemów gwarancji depozytów, Dz.Urz. UE L Nr 173.

Ustawa z dnia 10 czerwca 2016 roku o Bankowym Funduszu Gwarancyjnym, systemie gwarantowana depozytów oraz przymusowej restrukturyzacji, Dz.U. z 2020 r. poz. 842.

Ustawa z dnia 14 grudnia1994 roku o Bankowym Funduszu Gwarancyjnym, Dz.U. z 2014 r. poz.1866.

Ustawa z dnia 7 listopada 2008 roku o Komitecie Stabilności Finansowej, Dz.U. z 2008 r. nr 209, poz. 1317 ze zm.

Komunikat Komisji Europejskiej w sprawie stosowania reguł pomocy państwa w odniesieniu do środków wsparcia na rzecz banków w kontekście kryzysu finansowego, Dz.U. UE z 2013 r. C 216/01, pkt 65 .

Uzasadnienie rzadowego projektu ustawy o Bankowym Funduszu Gwarancyjnym, systemie gwarantowania depozytów oraz przymusowej restrukturyzacji, Druk sejmowy $\mathrm{nr} 215$.

\section{LITERATURA}

Fedorowicz M., Bankowy Fundusz Gwarancyjny jako organ przymusowej restrukturyzacji, [w:] Praktyczne i teoretyczne problemy prawa finansowego wobec wyzwań XXI wieku, red. J. Gliniecka, A. Drywa, W. Juchniewicz, T. Sowiński, Gdańsk 2017.

Jurkowska-Zeidler A., Bezpieczeństwo rynku finansowego w świetle prawa Unii Europejskiej, Warszawa 2008.

Jurkowska-Zeidler A., Światowe dobro publiczne, „Gazeta Bankowa” 2005.

Jurkowska-Zeidler A., Spór komisji nadzoru finansowego Abris Capital Partners. Międzynarodowe umowy o ochronie inwestycji (bit) pomiędzy państwami członkowskimi. V Prawo Unii Europejskiej, „Gdańskie Studia Prawnicze” 2019, nr 2.

Kropacz I., Stabilność systemu finansowego i bezpieczeństwo polskiego systemu gwarantowania depozytów, „Finanse i Prawo Finansowe” 2017, nr 4.

Kujawa S., Wdrożenie Dyrektywy Parlamentu Europejskiego i Rady 2014/49/UE z dnia 16.04.2014 r. w sprawie systemów gwarancji depozytów przez państwa członkowskie Unii Europejskiej, „Bezpieczny Bank” 2020, nr 4.

Kulesza A., Wplyw systemu gwarantowania depozytów na ryzyko niewyplacalności sektorów bankowych w wybranych krajach europejskich w latach 2004-2016, „Bezpieczny Bank” 2020.

Ofiarski Z., Istota i zakres kontroli wykonywanej przez Bankowy Fundusz Gwarancyjny, „Białostockie Studia Prawnicze” 2019, nr 23, s. 23.

Pomoc publiczna. Doświadczenia wybranych sektorów gospodarki, red. M. Kożuch, Kraków 2017.

Rada Stabilności Finansowej, Key Attributes of Effective Resolution Regimes for Financial Institutions, www.fsb.org (dostęp: 16.11.2021).

Raport roczny Bankowego Funduszu Gwarancyjnego za 2019 rok, Warszawa 20019.

Summers L., U.S. Economic Prospects: Secular Stagnation, Hysteresis, and the Zero Lower Bound, „Business Economics, National Association for Business Economics” 2014, nr 2.

Supernat J., Zarzadzanie, Wrocław 2005.

Sura R., Komentarz do art. 4, [w:] Ustawa o Bankowym Funduszu Gwarancyjnym, systemie gwarantowania depozytów oraz przymusowej restrukturyzacji, red. P. Zawadzka, P. Zimmerman, R. Sura, Warszawa 2017.

Szambelańczyk J., Miejsce i rola Bankowego Funduszu Gwarancyjnego w sieci bezpieczeństwa systemu finansowego w Polsce, „Bezpieczny Bank” 2005, nr 74.

Szczepańska O., Dobrzańska A., Zdanowicz B., Resolution, czyli nowe podejście do banków zagrożonych upadłością, Warszawa 2015.

Wojciechowski Ł., Bankowy Fundusz Gwarancyjny jako instytucja bezpieczeństwa finansowego w świetle wybranych aspektów funkcjonowania systemu gwarantowania depozytów, „Zeszyty Naukowe Wyższej Szkoły Ekonomii i Innowacji w Lublinie” 2016, nr 1. 
Zawadzka P., Komentarz do art. 5, [w:] Ustawa o Bankowym Funduszu Gwarancyjnym, systemie gwarantowania depozytów oraz przymusowej restrukturyzacji, red. P. Zawadzka, P. Zimmerman, R. Sura, Warszawa 2017.

Zygierewicz M., Bankowy Fundusz Gwarancyjny — potrzeby ewolucji działalności gwarancyjnej i pomocowej, „Bezpieczny Bank” 2005, nr 2. 